\title{
Strengthening Social Inclusion in Multicultural Societies Through Information Literacy*
}

\author{
Çok Kültürlü Toplumlarda Bilgi Okuryazarlığı Aracılığıyla \\ Sosyal Bütünleşmenin Artırılması
}

\author{
Esin Sultan OĞUZ** and Serap KURBANOĞLU***
}

\begin{abstract}
We live in an increasingly heterogeneous society. The rate of international migration has contributed to cultural diversity in many nations. Libraries of all types have started to address cultural and linguistic diversity while providing information sources and services. According to The IFLA Multicultural Library Manifesto (2008), each individual has the right to a full range of library and information services, and libraries should serve all members of the community without discrimination. Special attention should be paid to cultural and linguistic groups which are underserved such as minorities, refugees, immigrants, including those with temporary residence permits.

Public libraries are considered useful social instruments in the democratization of information. They are agents for social change and excellent tools for the integration of immigrants. They prepare immigrants for citizenship by introducing them to the values of their new nation, and frequently sustain them through the initial period of adaptation. They are spaces where patrons can readily access information, not only to increase their knowledge, but also to improve their abilities and skills in order to participate in society.

As the key for life-long learning and success not only in school and the work place but also in daily life, information literacy skills must be developed by immigrants, refugees and foreign residents in order for them to integrate into their adopted country. Knowing how to access, use and communicate information effectively will enable the social inclusion of newcomers. Therefore, developing special information literacy programs to equip such groups with information literacy skills should be among the priorities of public libraries.

In this study, the importance of information literacy skills in multicultural societies in terms of the social inclusion of immigrants will be underlined. Findings of a survey which has been conducted to ascertain information needs of foreign residents in Turkey and the level of fulfillment of their information needs will be presented. The findings of the research will also be used to make suggestions for developing information literacy programs which address the specific information needs of culturally and linguistically diverse communities.
\end{abstract}

Keywords: Information literacy, Public libraries, Multicultural society, Multilingual society, Foreign residents, Turkey

\footnotetext{
* An earlier version of this paper was presented at IFLA World Library and Information Conference, 2011.

** Asst.Prof., Yıldırım Beyazıt Univ ersity Department of Information Management (esinsultanoguz@ybu.edu.tr)

*** Prof.Dr.,Hacettepe University Department of Information Management (serap@hacettepe.edu.tr)
} 


\section{Öz}

Içinde yaşadığımız toplum giderek çeşitlenmektedir. Uluslararası göç hareketleri birçok ülkede kültürel çeşitliliği artırmaktadır. Kültürel ve dilsel çeşitliğe sahip toplumlarda bilgi kaynaklarının ve hizmetlerinin sağlanmasında her türden kütüphane adres gösterilmektedir. Uluslararası Kütüphane Dernekleri ve Kuruluşları Federasyonu (IFLA) tarafından yayımlanan Çok Kültürlü Kütüphane Bildirisi'ne göre toplumda her bireyin kütüphane ve bilgi hizmetlerine tam ve eksiksiz erişme hakkı vardır. Dezavantajlı gruplar olarak adlandıılan azınlıklar, göçmenler gibi kültürel ve dilsel çeşitliliğe sahip topluluklara bilgi hizmetlerinin sağlanmasında özel önem gösterilmelidir.

Halk kütüphaneleri bilginin demokratikleşmesinde sosyal aracı niteliğindeki önemli kurumlar arasındadır. Göçmenlerin sosyal ve kültürel bütünleşme sürecinde sosyal değişimin sağlanacağı yegâne kuruluşlar halk kütüphaneleridir. Ev sahibi ülkenin değerlerinin kavranması, vatandaşlık bilincinin kazandırılması ve yeni bir kültüre uyumun sağlanması aşamasında göçmenleri yeni hayatlarına hazırlarlar. Kütüphaneler kullanıcıların bilgiye erişmesini sağlamanın ötesinde onların toplumsal katılımını artırmak amacıyla bilgi ve becerilerini geliştirecek alanlar yaratırlar.

Örgün ve yaygın eğitimde, gündelik yaşamda yaşam boyu öğrenmenmenin kilit noktası olan bilgi okuryazarlığı becerileri göçmenler ve yabancılar tarafından göç ettikleri ülkeye uyum sağlayabilmeleri ve bu uyumu sürdürebilmeleri için geliştirmeleri gereken temel beceriler arasındadır. Bilgiye nasıl erişileceğinin ve kullanılacağının etkin bir şekilde öğrenilmesi göçmenler arasında sosyal bütünleşmeyi artırıcı faktörler arasındadır. Bu nedenle dezavantajlı gruplara yönelik özel hazırlanmış bilgi okuryazarlığı programları halk kütüphanelerinin öncelikleri arasında yer almalıdır.

Bu çalışmada, çok kültürlü toplumlarda bilgi okuryazarlığı becerileri göçmenlerin sosyal bütünleşmelerini artırıc bir faktör olarak ele alınmaktadır. Türkiye'de yaşayan yabancıların bilgi gereksinimlerinin belirlenmesi amacıyla uygulanan anket sonuçları, bilgi gereksinimlerinin önem düzeyi ve bu gereksinimlerin karşılanma düzeyi sunulmaktadır. Araştırma sonucunda elde edilen bulgular aynı zamanda kültürel ve dilsel çeşitliliğe sahip toplulukların özel bilgi gereksinimlerini karşılayacak bilgi okuryazarlığı programlarının geliştirilmesine yönelik öneriler sunmak amacıyla kullanılmıştır.

Anahtar sözcükler: Bilgi okuryazarlığı, Halk kütüphaneleri, Çok kültürlü toplum, Çok dilli toplum, Göçmenler, Türkiye

\section{Introduction}

Today, most countries around the world are linguistically and culturally heterogeneous. The proliferation of migration among countries has contributed to cultural diversity in many nations. In recent years, there has been an increase in the number of immigrant groups around the world. Over the past eight years, for instance, the number of foreigners living in EU countries has increased by 10.2 million. According to the 2010 population statistics of the EU, the total number of non-nationals (persons who are not citizens of their country of residence) living in the territory of the EU Member States is 31.9 million, representing $6.4 \%$ of the total EU population (Eurostat, 2010, pp. 1-6).

The problems of multicultural societies have been the subject of international debate for decades (Jönsson-Lanevska, 2005, p. 128). Although today most countries around 
the world are multicultural, many of their social problems, such as intercultural dialogue, mutual understanding, civic participation, social inclusion ${ }^{1}$, cultural integration and the social cohesion of newcomers in their host countries, remain unsolved.

Definitions concerning multiculturalism usually include the concept of the "social mosaic". Taylor et al. (1994), for example, defines multiculturalism as a "social mosaic of bounded and identifiable cultures co-habiting a common territory in the context of a single dominant culture". IFLA (2005) defines multiculturalism as "the coexistence of diverse cultures, where culture includes racial, religious, or [social] groups. [Multiculturalism] is manifested [through] behavior, cultural assumptions and values, patterns of thinking, and communicative styles".

Although the common factor in definitions of multiculturalism is the notion that all groups in a nation should have equal access to public resources, there are groups which are generally underserved in multicultural societies. Among the underserved are immigrant minorities or permanent settlers who possess languages and cultures which are distinct from those of the host society. Another group are those seeking asylum or refugees and residents with a temporary stay permit. A third group is migrant workers who are immigrants who do not intend to stay permanently. The fourth group is national minorities who are indigenous or long-established groups with a long-standing and distinct ethnic, linguistic, or cultural identity, distinct from that of the majority (IFLA, 2005).

There are many studies concerning the information literacy within immigrant communities are stressing on the health literacy (Kreps and Sparks, 2008; Andersen, Olives and Pereira, 2007) which are defining the difficulties by cultural barriers and economic challenges to accessing health information. In addition to that many other studies are mostly focus on importance of the language learning in the host country and representing remarks for a better integration in the society (Gilton, 2005 ; Currie and Cray, 2004). Accessing to information in a host country by retired immigrants has not been studied specifically in terms of multicultural library and information services. In this study, the term "multicultural" is used in its broadest sense to include all the above mentioned groups.

\section{Multicultural Libraries and Multicultural Library Services}

It has long been accepted that individuals who live in multicultural societies should be provided with equal opportunities to access economic, political and public resources. Moreover, they should be provided with opportunities to fulfill their self-potential, mainly through access to information and public education (Jönsson-Lanevska, 2005, pp. 128-129). This approach contends that libraries and other information services are

1 Social inclusion is defined as a process which ensures the opportunities and resources necessary for individuals to participate fully in economic, social and cultural life and enjoy a standard of living and well being that is considered normal in the society in which they live (Council of European Union, 2004). 
integral components of a multicultural society. IFLA (2009) also suggests that libraries should be tailored to their local populations in order to ensure equal access to public resources, and defines a multicultural library as one in which ethnic, linguistic and cultural groups are provided with library materials and information services in their preferred languages, reflecting their own cultures on an equitable basis. Multicultural library services include both the provision of multicultural information to all types of library users, and the provision of library services targeted specifically to underserved groups. This involves serving all members of the community, without discrimination, based on cultural and linguistic heritage; providing information in appropriate languages and scripts; ensuring access to a broad range of materials and services reflecting the community's needs; and employing staff members who reflect the diversity of the community and who are trained to serve the community's patrons (IFLA, 2008).

There has been an increase in the debate concerning the social inclusion, civic participation, and social cohesion of immigrants in their adopted countries. As a result, public libraries have emerged as one of the cultural mediators between foreign and native populations by developing a diverse range of services and diverse range of information sources. Public libraries bridge cultural divides by creating cultural harmony between people who are from different cultural backgrounds. Public libraries also recognize their responsibility to prepare immigrants for citizenship by introducing them to the values of their new nation, and frequently sustain them through the initial period of adaptation. Public libraries are useful social organizations where patrons not only can readily access information but also learn how to access information, and thus increase their knowledge and their ability to participate in civic affairs. Multicultural library services therefore play a key role in the social inclusion of immigrants.

Public libraries, with their role as a bridge builders in multicultural societies enable members of diverse cultural groups to enjoy their cultural heritage as it is written in their language; to keep in touch with what is going on in their former homelands by means of newspapers, magazines and the web; to become informed about the background and meaning of different cultural aspects of their new homeland and to find their way in society by providing community information, guiding them to it, and helping them have access to the resources they need. Furthermore, public libraries enable newcomers to learn the new country's language as a second language. Young members of these groups can also learn and practice the mother tongue of their parents through available media (Larsen, Jacobs and van Vlimmera, 2003, p.7).

By doing all this, public libraries play an important role in social engagement and formal and informal learning. They support newcomers adjusting to their new lives, and create a basis for understanding between different groups. As Simsova indicates (1992, pp. 32-33) in a multicultural community, the library acts as a catalyst to social integration. 
On the other hand, developing multicultural library services inevitably requires familiarity with the society in question. Librarians need to know which groups are represented in the community, in which numbers, and also need to learn more about the information needs of the members of these culturally diverse groups. Next to statistical and demographic knowledge of the immigrants, contact with these groups is of great importance. By developing services collaboratively with the immigrants, libraries learn more about their needs, mobilize their participation, and are able to reach out to them effectively with their services (Larsen, Jacobs and van Vlimmera, 2003, p.7).

Public libraries offer a wide range of services to members of culturally diverse groups as integral parts of their services. According to IFLA's guidelines for library services in multicultural populations (2009), the core actions of a multicultural library are as follows: to develop culturally diverse and multilingual collections and services; to allocate resources for the preservation of cultural expression and heritage; to provide access to library resources in appropriate languages through information organization and access systems; to develop marketing and outreach materials in appropriate media and languages to attract different groups to the library; and to develop programs supporting user education and information literacy skills.

\section{Importance of Information Literacy Skills and Services in Multicultural Communities}

Information literacy is a set of competencies that an informed citizen of an information society ought to possess to participate intelligently and actively in that society (Information literacy, 2011). Information literacy empowers people in all walks of life to seek, evaluate, use, and create information effectively to achieve their personal, social, occupational and educational goals. It is a basic human right which also promotes social inclusion (Aleksandria Proclamation, 2005).

Knowing how to access and use information effectively, in other words, possessing information literacy skills, increases the ability of individuals to participate in civic affairs. As the key for life-long learning and success, not only in school and the work place but also in daily life, information literacy skills must be developed by individuals in information societies, especially by immigrants, in order for them to integrate into their host country. To be information literate, a person must be able to recognize when information is needed and have the ability to locate, evaluate, and use, effectively the needed information (ALA, 1989). Knowing how to access, use and communicate information effectively will enable newcomers to find their way in society by acquiring community information and information about their rights. Therefore, developing information literacy instruction services to equip such groups with information literacy skills should be among the priorities of public libraries. Special attention should be paid to immigrants who suffer from cultural as well as linguistic barriers. 
Information literacy competences are vital for lifelong learning and closely related to "self-directed learning", "digital competences," and "social and civic competences". An information literate individual is capable to learn throughout his/her entire lifespan. Learning is an empowering activity in all senses. Harnessed together, information literacy and lifelong learning can substantially improve the set of choices and options for an individual in the context of personal, family and societal matters (IFLA, 2006). Information literacy skills provide individuals with pathways to improving their knowledge and competencies (IFLA, 2006). Such skills are vital for employability and can significantly improve the prospects of finding and keeping a satisfying job and moving up the career ladder as well as making cost effective and wise decisions regarding social and professional lives. It is also vital to eliminate social exclusion and to strengthen integration into society, especially for newcomers.

There is no doubt that well developed information literacy skills help: to promote social inclusion, personal and vocational empowerment; to maintain participative citizenship, the competitive advantage of individuals, employability and productivity; to improve personal choices and options; to enhance lifelong learning and to strengthen intercultural competences (Australian, 2006; Bundy, 2004; Dudziak, 2006; Garner, 2005). However, although the number of immigrants in today's societies is undeniably on the rise, there are very few specific information literacy instruction services which address the specific needs and linguistic diversity of multicultural communities; in other words services which are more responsive to emerging challenges posed by multiculturalism.

The current study wishes to address the lack of multilingual and multicultural sensitivity to information literacy instruction services and assess the disadvantageous situation of immigrants with respect to equal access to information and information services.

\section{A Research on Information Needs of Foreign Residents in Turkey}

In recent years, there has been an increase in immigration to Turkey, mostly from Europe. The number of European immigrants in 2000 is estimated to be 150,000 (TUIK, 2000). Although the number of immigrants to Turkey is on the rise, there is no short or long term plan to develop multicultural library and information services for immigrant communities. As Rasmussen and Kolarik (1981, p.25) have stated, "the notion of equality implies equal access to resources and services available in the community." As it stands right now, foreigners in Turkey are at a huge disadvantage with respect to equal access to information.

The aim of this study is to uncover the distinct information needs, especially with respect to citizenship, education, health, social services and practical issues, of foreign residents in Turkey, many of which need to be satisfied in order to facilitate their integration into Turkish society. Therefore, a survey was conducted to explore the importance of community information, information sources, and services to foreign residents and to what extent these needs are being satisfied. 
Didim, a small town located in Southern Turkey near Aydin, was selected as the location for this study due to its large European population. The number of immigrants in Didim has consistently risen since 2000, reaching a total of approximately 4,300 individuals (approx. 90\% are British) by 2011. Currently, there is a public library in Didim. Didim's public library collection consists of 13,000 books which circulate among its 3,200 members. Only $1.8 \%$ of patrons are foreign, and $3.8 \%$ of books are in languages other than Turkish. There is a lack of communication between the foreign population in Didim and the public library. This is mainly due to an absence of non-Turkish resources, technological mismatch, inadequate staff and lack of information regarding the specific information needs of the foreign population.

Within the current public library system, there is no coherent method of identifying and tracking the information needs of immigrant communities. In this study it is aimed to uncover the distinct information needs of the retired immigrants who are representing the largest immigrant community in the community. This study therefore also seeks to facilitate communication between service providers and patrons.

\section{Methodology}

This study has two basic research questions. Namely, what kind of community information, information sources and services do foreign residents require, and to what extent are these needs satisfied? Last 5 years there has been a significant increase in the number of foreign residents especially nearby the seaside towns in Turkey. Didim has been one of the very first towns that has been observed the most foreign residing.

In this study, the data was collected using an anonymous questionnaire developed by the authors. The survey was administered in 2010 through both printed and online questionnaires using a convenience sampling method on the European residents of Didim, Turkey.

The survey instrument consisted of a series of 26 questions, including an open ended question for additional comments (Question \#26, however no additional comments were made by participants). The first 9 questions sought to gain demographic information such as respondents' gender, age, nationality, level of education, residency type and the duration of their stay in Didim. Questions 10 to 13 were about the competency level of respondents in the Turkish language, computers, Internet and library usage. Questions 14 to 25 were formulated based on a five point Likert-scale (the least, less, quite, very, the most). Respondents were asked to rank each question/item from least to most, both for the level of importance and the level of fulfillment. Questions 14-17 (Section II) concerned information sources and library services; and Questions 18-25 (Section III) were about their information needs regarding health, education, sports and recreation and practical issues. 
The collected data were analyzed using PASW statistics software by the SPSS Corporation and descriptive statistics tests were used. In order to find out whether there is a significant difference between the importance and fulfilment level of respondents' information needs, the mean scores of these two variables were compared using the "paired samples $t$-test".

\section{Findings and Discussion}

The questionnaire was completed by 77 individuals, $40.3 \%$ of whom were female and $59.7 \%$ of whom were male, thus reflecting the overall gender-composition of the respondents. When the respondents are analyzed for age alone, we observe that the percentages for those below 50 are considerably smaller with 13\%. 62\% of respondents are between the ages of 50 to 59 and, $25 \%$ are over 60 . Thus, $87 \%$ of survey respondents are above the age of 50 . These are retirees from Britain who preferred to live in Didim due to its warmer climate and relatively lower cost of living.

All respondents are permanent residents and have been living in Didim for 2 to 9 years. With regards the length of their stay in Turkey per year, $88.3 \%$ of respondents indicated that it is more than 6 months while $11.7 \%$ indicated that it is between $4-5$ months.

Respondents were also asked about their level of education and their Turkish language proficiency. $83.1 \%$ of the respondents hold a high school diploma while the rest $(16.9 \%)$ have a university degree. As for the Turkish language proficiency level, almost half of the respondents (45.5\%) indicated their level as pre-intermediate. This is followed by the elementary level with $27.3 \%$, the intermediate level with $16.9 \%$, and the upper intermediate level with $10.4 \%$. Data shows that more than $80 \%$ of the respondents' Turkish language proficiency level is inadequate to look for and use information in the Turkish language. This necessitates the provision of library sources and services in English.

Respondents' computer, Internet and library competences were explored by asking them to rank their level from elementary to advanced. Almost half of the respondents' (48.1\%) computer competence level is indicated as intermediate while for the other half it is lower (18.2\% elementary level, 33.8\% pre-intermediate level). As for Internet competence, half of the respondents (49.4\%) indicated their level as pre-intermediate, $23.4 \%$ as elementary, and $27.3 \%$ as intermediate. With regards to library competence, $50.7 \%$ of respondents indicated their level as intermediate or above (9\% upperintermediate, $4 \%$ advanced); $7.8 \%$ as elementary, and $33.8 \%$ as pre-intermediate (Table I). Findings show that respondents are capable of using computers, the Internet, and libraries at least at the elementary level. However, since these competences are a prerequisite for finding and accessing information, the data indicates a need to develop these skills. 
Table I. Level of Computer, Internet and Library Competences

\begin{tabular}{lcccccccccccc}
\hline & \multicolumn{1}{c}{ Elementary } & \multicolumn{2}{c}{ Pre-Inter. } & \multicolumn{1}{c}{ Intermediate } & \multicolumn{2}{c}{ Upper-Inter. } & Advanced & \multicolumn{2}{c}{ Total } \\
\hline & $\mathbf{n}$ & $\%$ & $\mathbf{n}$ & $\%$ & $\mathbf{n}$ & $\%$ & $\mathbf{n}$ & $\%$ & $\mathbf{n}$ & $\%$ & $\mathbf{n}$ & $\%$ \\
\hline Computer & 14 & 18.2 & 26 & 33.8 & 37 & 48.1 & 0 & 0 & 0 & 0 & 77 & 100 \\
Internet & 18 & 23.4 & 38 & 49.4 & 21 & 27.3 & 0 & 0 & 0 & 0 & 77 & 100 \\
Library* & 6 & 7.8 & 26 & 33.8 & 29 & 37.7 & 7 & 9.1 & 3 & 3.9 & 71 & 92.2 \\
\hline
\end{tabular}

*6 respondents (7.8\%) didn't answer this question.

As mentioned earlier, in this study, respondents were asked to rank the level of importance as well as the level of fulfillment of their needs regarding certain information sources, services, and community information (including health, education, sports \& recreation and practical issues).

Based on a five-point Likert scale, ranging from 1 (the least) to 5 (the most), sources about local information and magazines received the highest mean scores for importance (4.2 and 4.1 respectively). These are followed by newspapers, DVDs, novels, other types of books and music CDs; with mean scores of 3.8, 3.8, 3.7, 3.1, and 2.9 respectively. Children's books and encyclopaedias are indicated as the least important information sources (with mean scores 1.8 and 1.7 respectively) (Table II). When the age and work status of respondents are taken into account, these results are expected. On the other hand, mean scores for fulfilment level of respondents' needs for these information sources remained under 2, with the exception of DVDs. The mean score for the fulfilment of the need for DVDs (2.3) can be explained by the number of DVD stores available in town. The data indicates that there is a problem accessing the information sources needed by the respondents.

Table II. Importance and Fulfilment Level of Information Sources

\begin{tabular}{lcccc}
\hline & M & SD & M & SD \\
\hline Novels & 3.7 & 0.5 & 1.5 & 0.5 \\
Newspapers & 3.8 & 0.3 & 1.1 & 0.3 \\
Books & 3.1 & 0.6 & 1.7 & 0.4 \\
Magazines & 4.1 & 0.5 & 1.3 & 0.4 \\
DVDs & 3.8 & 0.3 & 2.3 & 0.8 \\
Music CDs & 2.9 & 0.6 & 1.4 & 0.4 \\
Dictionaries & 2.1 & 0.8 & 1.3 & 0.4 \\
Encyclopedias & 1.7 & 0.6 & 1.3 & 0.4 \\
Children Books & 1.8 & 0.4 & 1.2 & 0.4 \\
Sources about local Information & 4.2 & 0.4 & 1.6 & 0.4 \\
\hline
\end{tabular}


In order to find out whether there is a significant difference between the importance and fulfilment level of respondents' needs for information sources, the mean scores of these two variables were compared based on the paired samples $t$ - test. Results indicate a statistically significant correlation between the ranks of each information source's importance and fulfillment scores [t $(76)=48.077, p<0.05]$. We can conclude that respondents are not satisfied with the information sources they rated as highly important (Figure 1).

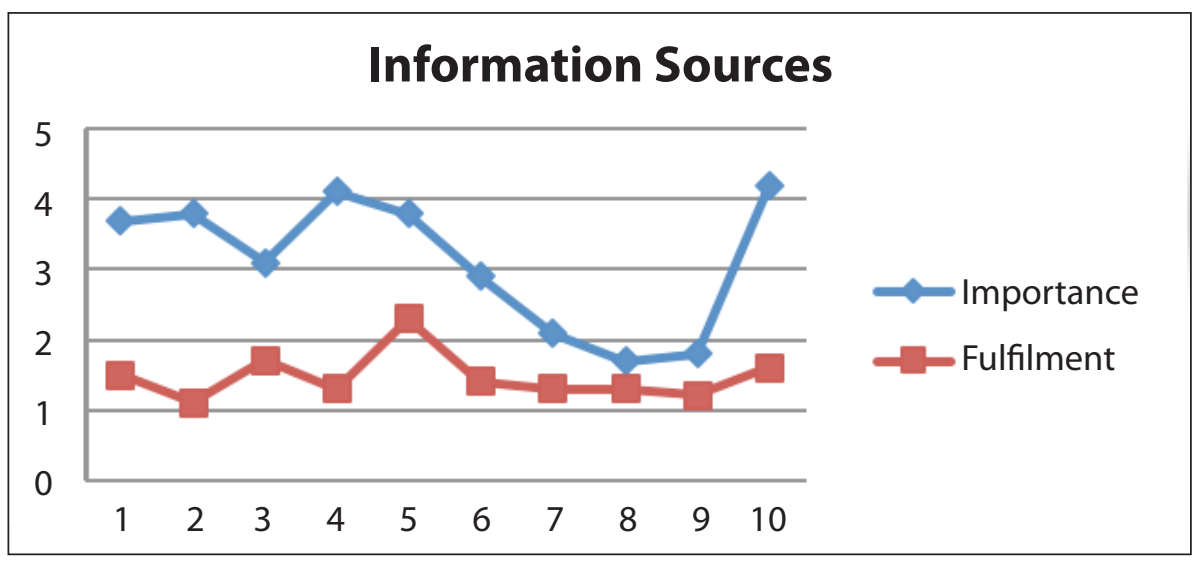

1. novels, 2. newspapers, 3. books, 4. magazines, 5. DVDs, 6. music CDs, 7. dictionaries, 8. encyclopaedias, 9. children books, 10. sources about local information

Figure 1. Importance and Fulfilment Level of Information Sources

As for information services, training on how to find local information and training on how to find information on the Internet received the highest mean scores of importance (4.4 and 4.2 respectively). It is followed by a collection in the languages I know, training on how to find information in the library, and borrowing materials (mean scores are 3.8, 3.5 and 3.5 respectively). Reference services are indicated as the least important information service (mean score is 3.2) (Table III). Results show that respondents prefer finding information they need by themselves; however they need training on how to do it, especially in terms of finding local information on the Internet. With regards to the fulfilment level of information services needs, mean scores indicate a very low level of satisfaction (all below 2). This proves that Didim public library fails to satisfy basic information needs regarding information sources and services for the foreign residences of the town. 
Table III. Importance and Fulfilment Level of Library Services

\begin{tabular}{lcccc}
\hline \multirow{2}{*}{ Library Services } & \multicolumn{3}{c}{ Importance } & \multicolumn{3}{c}{ Fulfilment } \\
\cline { 2 - 5 } & $\mathbf{M}$ & SD & $\mathbf{M}$ & SD \\
\hline A collection in the languages I know & 3.8 & 0.3 & 1.8 & 0.3 \\
Borrowing materials & 3.5 & 0.5 & 1.5 & 0.5 \\
Reference services & 3.2 & 0.5 & 1.7 & 0.4 \\
Training on how to find information in the library & 3.5 & 0.4 & 1.8 & 0.3 \\
Training on how to find information on the Internet & 4.2 & 0.4 & 1.6 & 0.4 \\
Training on how to find local information & 4.4 & 0.5 & 1.4 & 0.5 \\
\hline
\end{tabular}

The importance and fulfilment level of respondents' needs for information services were compared. The result of the paired samples $t$-test indicated that there was a statistically significant correlation between the ranks of each information service's importance and fulfillment scores [t $(76)=52.248$ and $p<0.05]$. The conclusion is that respondents are not satisfied with the library services that they rated as highly important (Figure 2).

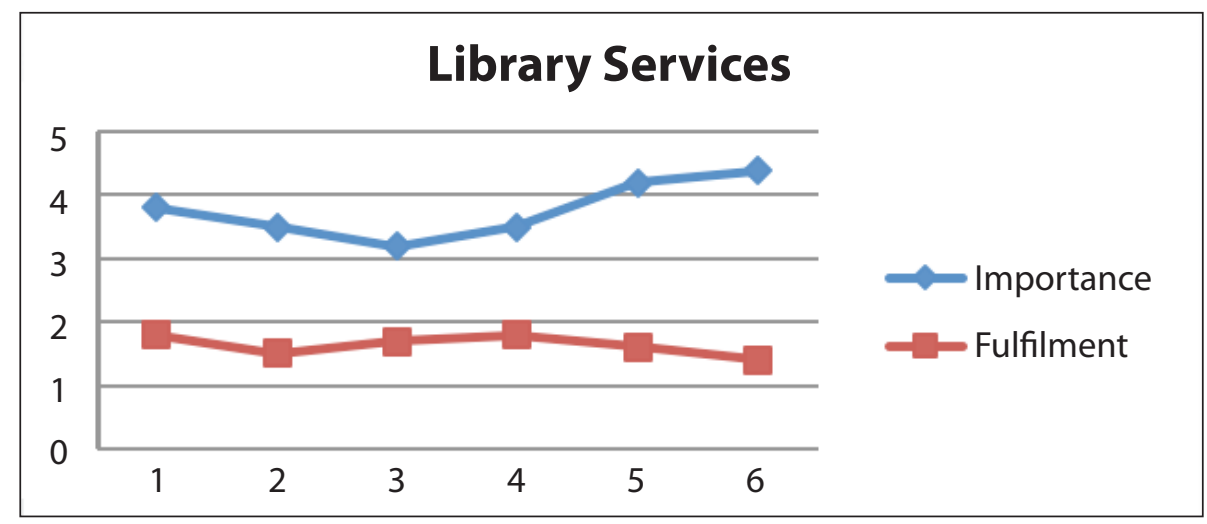

1. a collection in the languages i know, 2. borrowing materials, 3. reference services, 4. training on how to find information in the library, 5. training on how to find information on the Internet, 6. training on how to find local information

Figure 2. Importance and Fulfilment Level of Library Services 
Respondents were also asked to rank the level of importance as well as the level of fulfillment of their needs regarding community information such as information on health, education, sports and recreation and practical issues.

Eleven items were listed under health information. Information about emergency services, health insurance, health centres, health services, services for the disabled, and local diseases scored highly (with mean scores 4 or above). On the other hand information on things to do after child birth and mother \& child care scored least at 2.6 and 2.5 respectively (Table IV). When the average age of the respondents are taken in to consideration this is expected. When we compare the level of importance with the level of fulfilment of health information, we find that services for the disabled and local diseases are the least satisfied information needs, even though they are among the most important.

Table IV. Importance and Fulfilment Level of Health Information

\begin{tabular}{lcccc}
\hline \multirow{2}{*}{ Health Information } & \multicolumn{2}{c}{ Importance } & \multicolumn{2}{c}{ Fulfilment } \\
\cline { 2 - 5 } & $\mathbf{M}$ & SD & M & SD \\
\hline Health centers (hospitals, clinics, & 4.2 & 0.4 & 3.2 & 0.7 \\
dental clinics, etc) & 4.1 & 0.3 & 3 & 0.7 \\
Health services & 4 & 0.5 & 1.5 & 0.5 \\
Local diseases & 4.3 & 0.4 & 2.4 & 0.4 \\
Health insurance & 4.4 & 0.5 & 2.7 & 0.4 \\
Emergency services & 4.1 & 0.5 & 1.4 & 0.4 \\
Services for the disabled & 2.6 & 0.6 & 1.5 & 0.5 \\
Things to do after child birth & 3.7 & 0.4 & 1.5 & 0.4 \\
Things to do after death & 2.5 & 0.5 & 3.6 & 0.4 \\
Mother \& child care & 3.4 & 0.4 & 1.2 & 0.4 \\
Pharmacies and pharmacology & 3.5 & 0.4 & 1.2 & 0.4 \\
Family doctor & & & &
\end{tabular}

The relationship between the importance and fulfilment level of the health information is found to be statistically significant based on the paired samples $t$ - test [t $(76)=66.887$ and $p<0.05]$. This can be interpreted as that the respondents are not satisfied with the health information they rated as highly important (Figure 3). 


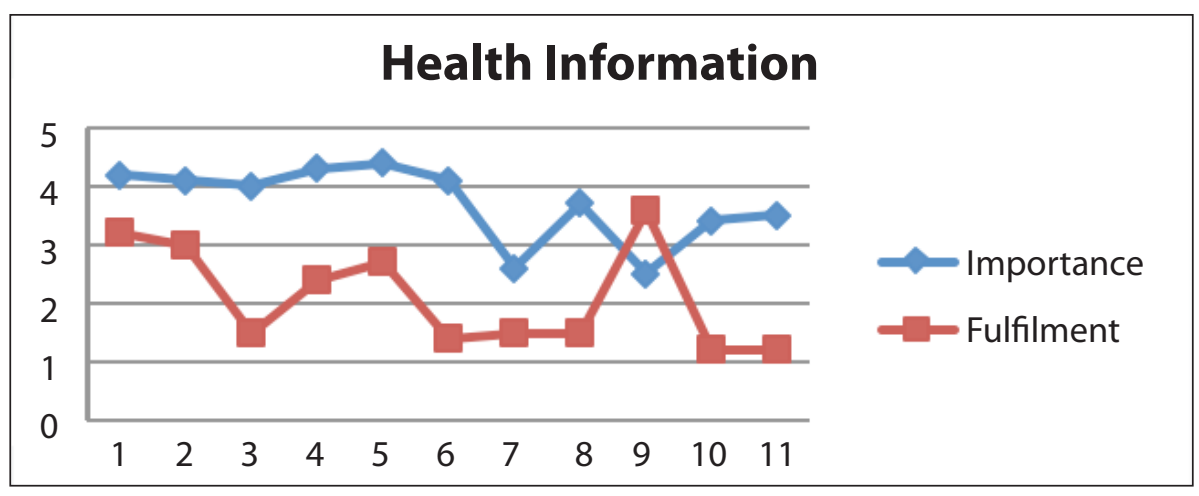

1. health centers, 2. health services, 3. local diseases, 4. health insurance, 5. emergency services, 6. services for the disabled, 7. things to do after child birth, 8. things to do after death, 9. mother \& child care, 10. pharmacies and pharmacology, 11. family doctor

Figure 3. Importance and Fulfilment Level of Health Information

The nine items listed under educational information cover both formal and adult education. Information about adult education received the highest score (4.4). Information about free education services provided by municipality, services provided by libraries, libraries, and translation and interpretation services (mean scores are 3.9, 3.9, 3.6 and 3.2 respectively) are among the items that received the highest scores. On the other hand, items concerning school and pre-school education received the lowest mean scores (below 2) (Table V). The level of importance indicated for language courses (mean score is 1.7) shows that respondents have no interest in taking language courses, including Turkish. This can be explained by the demographic profile of the respondents. As stated earlier, respondents are retirees with an average age over 50 . With regards to the fulfilment level of educational information, the highest mean score is 2.1 (for translation and interpretation services). For the rest, mean scores are very low (below 2).

Table V. Importance and Fulfilment Level of Educational Information

\begin{tabular}{lcccc}
\hline \multirow{2}{*}{ Educational Information } & \multicolumn{2}{c}{ Importance } & \multicolumn{2}{c}{ Fulfilment } \\
\cline { 2 - 5 } & M & SD & M & SD \\
\hline Free education services provided by municipality & 3.9 & 0.4 & 1.3 & 0.4 \\
Adult education programs & 4.4 & 0.5 & 1.4 & 0.5 \\
Schools for formal education & 1.7 & 0.4 & 1.1 & 0.3 \\
School registration & 1.0 & 0.2 & 1 & 0.2 \\
Pre-school education & 1.3 & 0.4 & 1.2 & 0.4 \\
Libraries & 3.6 & 0.5 & 1.9 & 0.6 \\
Services provided by libraries & 3.9 & 0.5 & 1.6 & 0.6 \\
Language courses & 1.7 & 0.6 & 1.1 & 0.3 \\
Translation and interpretation services & 3.2 & 0.4 & 2.1 & 0.7 \\
\hline
\end{tabular}


Correlation between the two values, level of importance, and level of fulfilment regarding the educational information is also found to be statistically significant [t (76) $=52.896$ and $p<0.05$ ] (Figure 4).

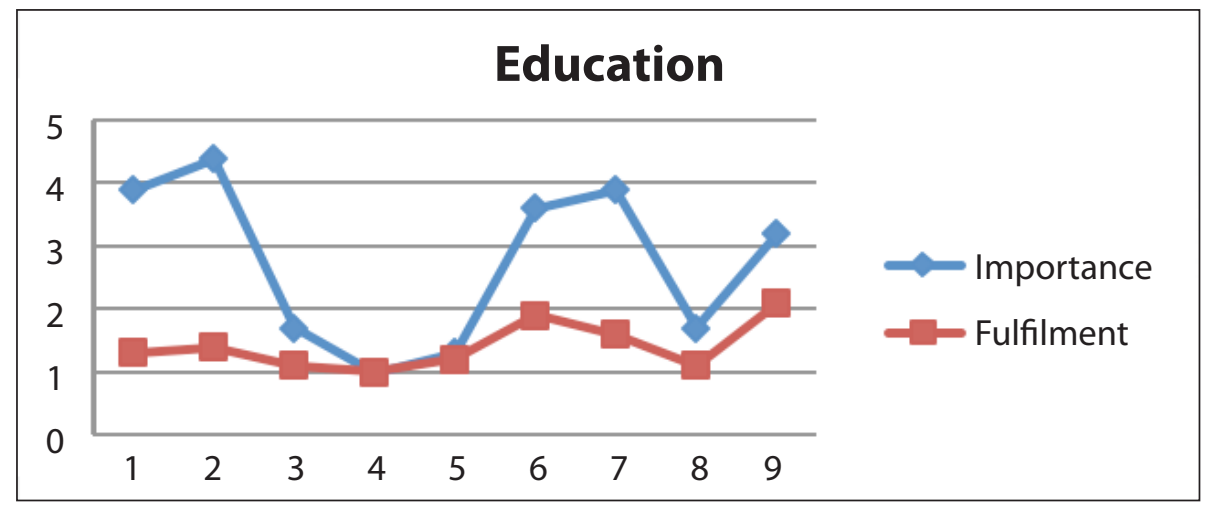

1. free education services provided by municipality, 2. adult education programs, 3. schools for formal education, 4. school registration, 5. pre-school education, 6. libraries, 7. services provided by libraries, 8. language courses, 9. translation and interpretation services

Figure 4. Importance and Fulfilment Level of Educational Information

For sports and recreational issues, respondents gave the most importance to festivals, fairs, and local activities (mean score is 4.5). This is followed by information about cultural activities, travel insurance, tourism information, and local excursions (mean scores are 4.4, 4.3, 4.1, and 4 respectively). The least important information needs are activities on religious days/holidays and addresses of churches (mean scores are 1.5 and 1.7, respectively). As for the fulfillment level of need, information about festivals, fairs, \& local activities, other cultural activities and local excursions received the highest scores, 3.4, 3.1 and 2.8, respectively (Table VI). This can be due to the promotion of these activities both by organizers and the local government. The mean scores for the fulfillment level of the remaining recreational information are unsatisfactory (below 2 ). 
Table VI. Importance and Fulfilment Level of Sports and Recreational Information

\begin{tabular}{lcccc}
\hline \multirow{2}{*}{ Sports and Recreational Information } & \multicolumn{2}{c}{ Importance } & \multicolumn{2}{c}{ Fulfilment } \\
\cline { 2 - 5 } & $\mathbf{M}$ & SD & M & SD \\
\hline Activities on religious days/holidays & 1.5 & 0.7 & 1.8 & 0.7 \\
Addresses of churches, synagogues etc. & 1.7 & 0.8 & 1.2 & 0.4 \\
Cultural activities & 4.4 & 0.5 & 3.1 & 0.6 \\
Tourism information & 4.1 & 0.6 & 1.9 & 0.5 \\
Transportation information & 3.6 & 0.7 & 1.8 & 0.5 \\
Travel insurance & 4.3 & 0.5 & 1.7 & 0.4 \\
Festivals, fairs, local activities & 4.5 & 0.5 & 3.4 & 0.4 \\
Sports clubs / amateur teams & 2.8 & 0.7 & 1.6 & 0.4 \\
International social services/projects/activities & 2.5 & 0.6 & 1.1 & 0.3 \\
Local excursions & 4 & 0.5 & 2.8 & 0.5 \\
\hline
\end{tabular}

Correlation between the importance and fulfilment of recreational information needs of respondents was found to be statistically significant $[t(76)=35.564$ and $p<0.05]$. Looking at the overall mean scores, it can clearly be observed that respondents are not satisfied with the information on sports and recreation, which they rated as highly important (Figure 5).

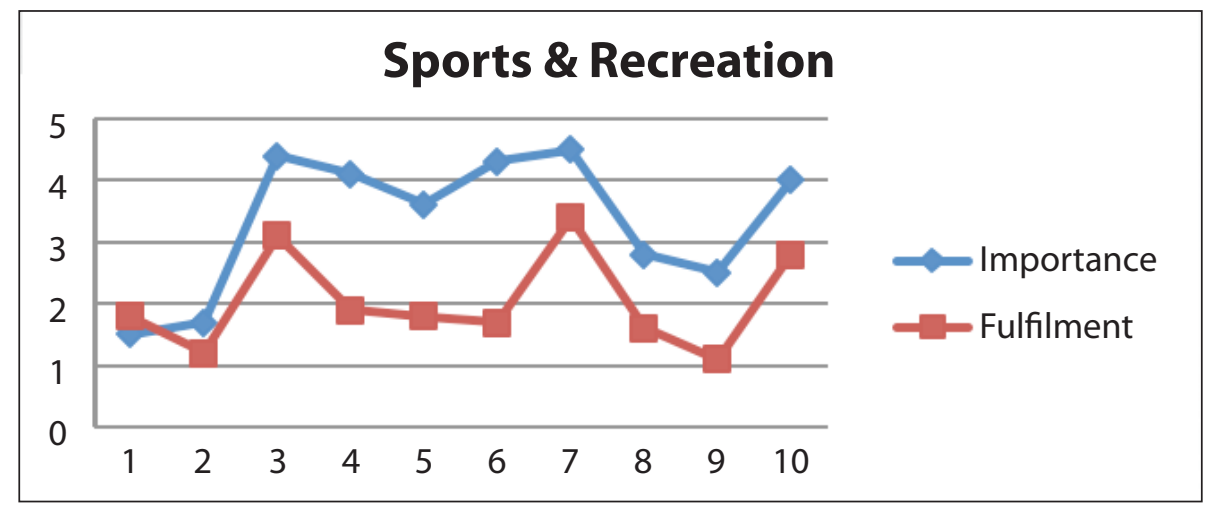

1. activities on religious holidays, 2. addresses of churches, 3. cultural activities, 4. tourism information, 5. transportation information, 6. travel insurance, 7. festivals, fairs, local activities, 8. sports clubs/amateur teams, 9. international social services/projects/activities, 10. local excursions

Figure 5. Importance and Fulfilment Level of Sports and Recreational Information 
Practical information concerning daily issues, residence permits, banking (opening accounts, leasing, customer services), personal and property safety, consumer rights/affairs, orientation to new culture and life, housing (renting, buying, etc., official procedures), pharmacy 24/7, and making connections in the community (associations, charity) received higher scores (with mean scores 4 or above) from respondents. Information about employment (job searching/finding services), work permits and driving licenses received the lowest scores, $1.8,2.3,2.8$, respectively (Table VII). This is because most of the residents are senior retirees with regular salaries.

In spite of the high importance assigned to particular types of practical information, level of fulfilment is quite low. This is especially true for information about consumer rights, new culture and orientation to life, social security, personal and property safety, and public amenities. Pharmacy 24/7, banking (opening accounts, leasing, customer services) and maintenance \& repairing services are the only information needs with mean scores of fulfilment above 2 (2.9, 2.9 and 2.1 , respectively).

Table VII. Importance and Fulfilment Level of Practical Information

\begin{tabular}{lcccc}
\hline \multirow{2}{*}{ Practical Information } & \multicolumn{2}{c}{ Importance } & \multicolumn{3}{c}{ Fulfilment } \\
\cline { 2 - 6 } & $\mathbf{M}$ & SD & M & SD \\
\hline Pharmacy 24/7 & 4.2 & 0.4 & 2.9 & 0.5 \\
Consumer rights/affairs & 4.4 & 0.5 & 1.6 & 0.4 \\
Banking (opening accounts, leasing, customer services) & 4.5 & 0.4 & 2.9 & 0.6 \\
Housing (renting, buying, etc., official procedures) & 4.3 & 0.4 & 1.9 & 0.6 \\
Making connections in the community (associations, charity) & 4 & 0.4 & 1.8 & 0.3 \\
Information about the new culture and orientation to life & 4.4 & 0.4 & 1.6 & 0.5 \\
Employment (job searching/finding services) & 1.8 & 0.5 & 1.6 & 0.4 \\
Residence permits & 4.6 & 0.4 & 1.6 & 0.4 \\
Work permits & 2.3 & 0.7 & 1.3 & 0.4 \\
Driving licenses & 2.8 & 0.6 & 1.8 & 0.3 \\
Retailers & 3.9 & 0.6 & 1.8 & 0.6 \\
Maintenance \& repair services of all sorts & 3.4 & 0.6 & 2.1 & 0.5 \\
Telecommunication services (telephone and Internet) & 3.4 & 0.6 & 1.9 & 0.6 \\
Marriage and divorce procedures & 3.6 & 0.4 & 1.5 & 0.5 \\
Social security & 3.9 & 0.4 & 1.5 & 0.5 \\
Personal and property safety & 4.5 & 0.4 & 1.8 & 0.3 \\
Public Amenities (police station, post office, fire department) & 3.5 & 0.4 & 1.8 & 0.3 \\
\hline & & & &
\end{tabular}




\section{Practical Information}

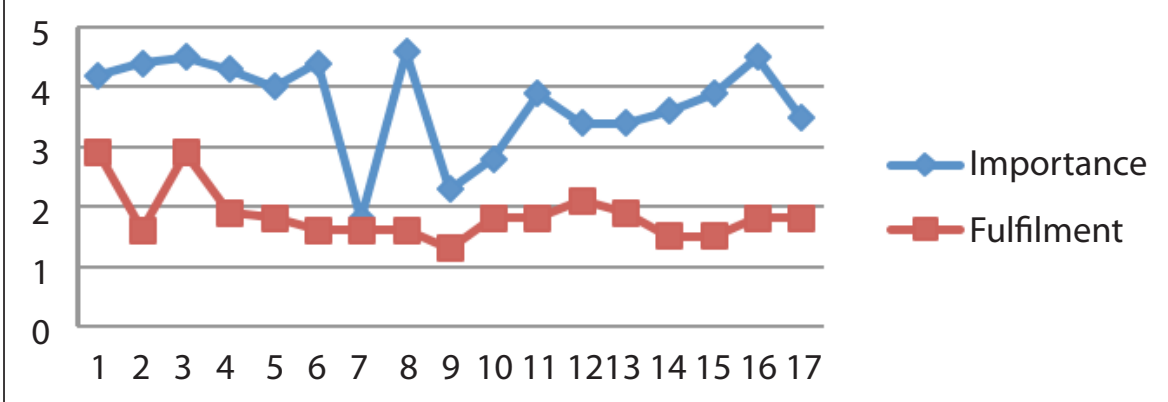

1. pharmacy $24 / 7$, 2. consumer rights, 3. banking, 4. housing, 5. associations, charity, 6. orientation to new culture, 7. employment, 8. residence permits, 9. work permits, 10. driving licenses, 11. retailers, 12. maintenance \& repair services, 13. telecommunication services, 14. marriage and divorce procedures, 15. social security, 16. safety, 17. public amenities

Figure 6. Importance and Fulfilment Level of Practical Information

Information listed under "practical information" can be considered as "survival information" for newcomers and is essential for their adaptation to the host country. However, paired samples $t$ - test show that there is a statistically significant correlation between the rank of information importance and mean fulfillment scores $[t(76)=94.660$ and $p<0.05]$. Overall scores for mean values show that respondents are not satisfied with the provision of practical information, which they rated as highly important (Figure 6).

\section{Conclusion and Suggestions}

Individuals who live in multicultural societies should be provided with equal opportunities to access information and information services. Multicultural libraries must provide access to a broad range of materials in appropriate languages and services which reflect the community's needs. Among the services multicultural libraries offer, programs supporting user education and information literacy skills are of the utmost importance, mainly because information literacy skills promote social inclusion and increase the ability of newcomers to participate actively in civic affairs.

Multicultural library services, on the other hand, should be developed based upon knowledge of the groups represented in the community and their needs. Such data will ensure that services are not developed and provided based upon assumptions. Data can be obtained by conducting a survey for community analysis as well as needs assessment. 
In this study a survey was carried out in order to make suggestions for multicultural library service provision, especially for information literacy instruction services, based on factual data collected on distinct information needs of foreign residents of Didim, Turkey.

Findings of the community analysis indicate that most of the respondents (87\%) are above the age of 50 and are retirees and permanent residents who preferred to move to Didim due to its climate and relatively lower cost of living. They are mainly high school graduates and data shows that more than $80 \%$ of the respondents'Turkish language proficiency level is inadequate (either elementary or pre-intermediate) to look for and use information in the Turkish language. This necessitates the provision of library sources and services in English. Findings show that respondents are capable using computers, the Internet and libraries at least at the elementary level. However, since these competences are pre-requisites for finding and accessing information, the data indicates a necessity for developing these skills.

Furthermore, the findings of the needs analysis indicate that books on local information and magazines are the most important information sources for respondents. These are followed by newspapers, DVDs, novels, other types of books, and music CDs. On the other hand, respondents indicated a very low level of satisfaction of their needs for these information sources. The fulfilment level of collections in the language they know is also very low, in spite of the high level of importance indicated by respondents. This can be explained by the inadequate collections of the local public library in languages other than Turkish. As for information services, training on how to find local information and how to find information on the Internet are indicated as most important, while reference services are indicated at least important. Results show that respondents prefer finding information by themselves; however they need training on how to do it. With regards to fulfilment level of information services needs, findings suggest that Didim public library fails to provide the most basic information sources and services for its multicultural community. This suggests the necessity of making the existing library system more immigrant-friendly and more responsive to immigrants' needs.

When participants are asked to rank the level of importance of their needs regarding information on health, education, sports and recreation and practical issues, it becomes clear that they have special information needs under each category based on their demographic characteristics. Their most important information needs can be listed as follows: emergency services; health insurance; health centres; health services; services for the disabled; local diseases; adult education; festivals, fairs, and local activities; other cultural activities; travel insurance; tourism; local excursions; residence permit; banking (opening accounts, leasing, customer services); personal and property safety; consumer rights/affairs; orientation to culture and life; housing (renting, buying, etc., official procedures); pharmacy 24/7; and making connections in the community (associations, charity, etc.). 
Further statistical analysis has shown that there is a significant correlation between the importance and fulfilment level of respondents' need for information sources and services. It is the same for community information. A conclusion that can be drawn from these results is that respondents are unsatisfied with the information, information sources and information services that they rated as highly important. On the other hand community information is considered "survival information" for newcomers, and essential to the adaptation of newcomers to their host country.

Such findings indicate a serious need for well developed information literacy skills. This is only possible through information literacy instruction programs which are specifically developed to equip these culturally and linguistically diverse groups with these essential skills. Based on these findings, our first suggestion, in long term, is to improve the existing public library system with respect to its multilingual and multicultural collection and services, making it more responsive to the distinct needs of foreign residents in the area. Developing a web based multilingual information literacy tutorial focused on how to find local and community information could be a short term suggestion. A web-based multilingual information literacy tutorial will have the potential to attract social groups, very much like foreign residents in Didim, who may lack language skills; who may not have a chance to access a well developed multilingual library; and who do not traditionally engage in formal education. Self-learning could be one of the most important mechanisms for obtaining skills and competences when there is a language barrier between library staff. It can also create a good alternative when it is not possible to recruit staff with required qualifications. Moreover, webbased instruction presents new opportunities for e-learning, especially for groups (such as immigrants) at risk of exclusion from public services, learning, and civic engagement. Use of web-based technology for teaching will also facilitate learning by making it possible practically anywhere and anytime by anybody.

As for providing community information, developing a multilingual portal could also be a good solution. There are some successful examples in other European countries (http://www.finfo.dk/, http://www.infopankki.fi/, http://www.interkulturellebibliothek. de/ , http://www.bazar.deichman.no/, http://www.multikulti.org.uk/ , http://www.ainp. $\mathrm{nl} /$ ). However, information literacy skills remain the key skills to access any kind of information which is not included in such portals.

A final conclusion which can be drawn from the findings of this research is that community analysis and needs assessment are necessary to develop the most appropriate information services for culturally diverse communities. As for information literacy training, specific programs should be prepared based on the results of community and needs analysis in order to be able to address the distinct needs of culturally diverse groups. How to find community information, including practical information for daily needs, social and civic rights, and e-government applications 
should be considered as one of the key components for such a program. Some of the conventional issues which are addressed in almost all information literacy training programs including scholarly use and communication of information (i.e. how to cite information sources, and how to use scientific databases), are also unnecessary in such programs. Final decisions about the content of an information literacy program should be based on factual data collected from the members of the target community.

\section{References}

ALA (1989). Presidential Committee on Information Literacy: Final report. Retrieved May 7, 2011 from http://www.ala.org/ala/mgrps/divs/acrl/publications/whitepapers/presidential.cfm

Aleksandria proclamation on information literacy and lifelong learning: Beacons of the information society. (2005). Retireved May 7, 2011 from http://archive.ifla.org/III/wsis/BeaconlnfSoc.html

Anderson T.B., Olives, T., Larsen, K., and Pereira, A. (2007). Health literacy in native Spanish speaking immigrants in Minneapolis. Travel Medicine and Infection Disease, 5(6), 410.

Australian Library and Information Association Statement on Information Literacy for All Australians. (2006). Retrieved May 7, 2011 from http://www.alia.org.au/policies/information.literacy.html

Bundy, A. (Ed). (2004). Australian and New Zealand information literacy framework: principles, standards and practice (2nd ed). Adelaide: ANZIIL.

Currie, P. and Cray, E. (2004). ESL literacy: language practice or social practice? Journal of Second Language Writing, 13(2), 111-132

Dudziak, E.A. (2006). Information literacy as an emancipatory process directed to social inclusion in a knowledge society. Paper presented at IFLA General Conference and Council World Library and Information Congress, Seoul, Republic of Korea.

Eurostat. (2010). Population and social conditions, Retrieved March 25, 2011 from http://epp. eurostat.ec.europa.eu/cache/ITY_OFFPUB/KS-SF-10-045/EN/KS-SF-10-045-EN.PDF

Council of European Union. (2004). Joint Report on Social Inclusion . Retrieved April 28, 2011 from http://ec.europa.eu/employment_social/soc-prot/soc incl/final_joint_inclusion_report_2003_ en.pdf

Garner, S.D. (ed.) (2006). High-level colloquium on information literacy and lifelong learning: Report of a meeting sponsored by the United Nations Education, Scientific, and Cultural Organisation (UNESCO), National Forum on Information Literacy (NFIL) and the International Federation of Library Associations and Institutions (IFLA), Bibliotheca Alexandrina, Alexandria, Egypt November 6-9, 2005. Retrieved May 7, 2011 from http://unesdoc.unesco.org/ images/0014/001448/144820e.pdf

Gilton, D.L. (2005). Culture shock in the library: Implications for information literacy instruction. Research Strategies, 20(4), 424-432.

IFLA. (2005). Defining multiculturalism. Retrieved October 15, 2010 from http://www.ifla.org/VII/ s32/index.htm 
IFLA. (2006). Guidelines on information literacy for lifelong learning. Retrieved 14 April, 2011 from http://www.ifla.org/files/information-literacy/publications/ifla-guidelines-en.pdf

IFLA. (2008). Multicultural library manifesto. IFLA Section on Library Services to Multicultural Populations Retrieved April 14, 2011 from http://archive.ifla.org/VII/s32/pub/ MulticulturalLibraryManifesto.pdf

IFLA. (2009). Multicultural communities: guidelines for library services ( $3^{\text {rd }}$ edition), Retrieved October 15, 2010 from http://archive.ifla.org/VII/s32/pub/guide-e.pdf

Information literacy. Wikipedia. Retrieved May 8, 2011 from http://en.wikipedia.org/wiki/ Information_literacy

Jönsson-Lanevska, Y. (2005). The gate to understanding: Swedish libraries and Immigrants. New Library Word 106(3/4),128-140.

Kreps, G.L. and Lisa Sparks. (2008). Meeting the health literacy needs of immigrant populations. Patient Education and Counseling 71(3), 328-332.

Larsen, J.I., Jacobs, D.L., and van Vlimmera, T. (2003). Cultural Diversity: How public libraries can serve the diversity in the community. Retrieved January 12, 2011 from http://conferences.alia.org.au/ alia2004/pdfs/vlimmeren.t.paper.pdf

Multicultural Center Prague (2005). Libraries for all: the role of the public libraries in a multicultural society, Retrieved February 13, 2011 from http://www.mkc.cz/uploaded/download/Regional_ report_eng.pdf

Rasmussen, R. and Kolarik, I. (1981). Library services in multicultural Australia. Multiculturalism and libraries. In Proceedings of the National Conference on Muliculturalism and Libraries. (pp. 7-11). Melbourne: Monash University, Australia.

Simsova, S. (1992). Multicultural Populations: Their nature and needs. In F. Zielinska and F.T. Kirkwood. (Ed.), Multicultural Librarianship: An International Handbook (pp.11-18). München: K.G. Saur.

Taylor, C., Appiah, K.A., Habermas, J. Rockerfellar, S.C., Walzer, M. and Wolf, S. (1994). Multiculturalism: Examining the politic of recognition. Princeton, NJ: Princeton University.

TÜiK, (2010). Ülkelere gore yurtdışından gelen göç, Retrieved March 15, 2011 http://www.tuik. gov.tr/PrelstatistikTablo.do?istab_id=167 